\title{
Imagining the Witch: A Comparison between Fifteenth-Century Witches within Medieval Christian Thought and the Persecution of Jews and Heretics in the Middle Ages
}

\author{
Lily Climenhaga
}

This paper will examine how the prominent image of the witch in Christian thought during the early modern period emerged from earlier images of the non-Christian Other, Jews and heretics for example. To do so the beliefs surrounding the "rituals" and "practices" of witches seen during the witch-craze of the fifteenth century are compared and contrasted with the images of Others within medieval Christian society. To do so a variety of both primary and secondary scholarship on the persecution of witches, heretics, and Jews during the Middle Ages and the early modern period.

\section{Introduction}

The witch trials and persecution of witches in Europe occurred throughout the later Middle Ages as well as the early modern period, reaching its height between the fifteenth to the seventeenth century. Around 110,000 men and women were tried as witches across European nations and American colonies between 1450 and 1750 and about 60,000 were executed. ${ }^{1}$ The "witch craze" of the early modern period has been examined by social anthropologists and historians, as a result there is a multiplicity of theories why the witch emerged within medieval European society as a Saidian Other. ${ }^{2}$ It is vital to recognize that the image of the witch, as seen during the "witch craze," did not come into existence in 1450 at the onset of mass witch trials. The beliefs during this period that were important to the Christian imagining of witches were a pact with the Devil, the night-ride, and the nocturnal meetings, which later transformed into the idea of the 'witches' Sabbath.' which supposedly took place during these nocturnal meetings became equally important: host desecration, diabolical orgies, infanticide and cannibalism. ${ }^{4}$ These beliefs were derived from preexisting myths and stereotypes associated with religious groups outside of Christianity such as Jews and heretics.

"Magic" acted as a description for individuals or groups who did not subscribe to the perceived societal norms of the medieval Christian community. Jews and heretics, the principle Others within Medieval Europe, existed outside of the societal norms and played an important role in the formation of the Christian perception of witches and witchcraft. Common elements existed between stories surrounding Jews, heretics, and witches. These beliefs created the preliminary conditions

\footnotetext{
1 The term "witch craze" is employed by Apps and Gow in Male Witches in the Early Modern Europe this paper will also employ this term, however, as the actual "witch-craze" between 1450 and 1750 is not the main focus of the paper it will use the term minimally.

Lara Apps and Andrew Gow, Male Witches in Early Modern Europe (Manchester: Manchester University Press, 2003$), 25$.

2 The concept of the Other was explored in Edward Said's Orientalism (New York: Vintage Books: 1978)

3 The word Sabbat is also commonly used in reference to the witches' Sabbath. For the sake of this paper I will refer to the nocturnal meetings Christians believed the witches to be holding as the witches' Sabbath.

4 Jeffrey B. Russell and Brooks Alexander, A History of Witchcraft: Sorcerers, Heretics and Pagans (London: Thames \& Hudson, 2007), 55.

5 Karen Jolly, "Medieval Magic: Definitions, Beliefs, Practices," in Witchcraft and Magic in Europe: The Middle Ages, ed. Bengt Ankarloo and Stuart Clark (Philadelphia: University of Pennsylvania Press, 2002), 6.
} 
necessary for the mass persecution and intolerance toward witches and became inherent to the idea of the witch as the diabolical Other within Medieval Christian thought. In Witchcraft and Magic in Europe: The Middle Ages, Karen Jolly identifies three distinct periods within European history outlining the gradual shift in Christian thought surrounding the idea of magic. The first period identified by Jolly is the "conversion period," 300 to 1100, when early Christianity began to spread across Europe adopting older pagan traditions and practices as it went. In this period the image of the diabolical Other formed. However, it was not until Jolly's second period during the twelfth century that this image was solidified in Christian thought. The third period began in the late fourteenth and early fifteenth centuries at the outbreak of the "witch-craze." The majority of the sources and examples examined will come out of Jolly's first and the second period using third period beliefs as a point of reference. ${ }^{7}$ The periods identified by Jolly are extremely useful as a reference for the developmental process of witchcraft in Christian thought. However, as with any system of reference Jolly does have a tendency to use these periods as an oversimplified categorization of events. Still, the categories given by Jolly provide a basic clarification of when different beliefs about witches began to emerge.

\section{Pact with Satan}

Throughout the "conversion period" of medieval society, there were few charges of purely witchcraft. Instead the concept of "magia", the early precursor to magic, was related to pagan and the Roman state religion and "superstitio" was related to the idea of false religion and beliefs. ${ }^{8}$ From as early as $107 \mathrm{CE}$, sources such as Ignatius of Antioch's Contra Haereticos link heresy and witchcraft to a pact with Satan. Simon Magus, an early heretic and "chief opponent" to the church, also supposedly had a pact with the devil. The Magus legend represented an early attack on Christianity, an attack countered by Paul. ${ }^{9}$ Legends and lore about Magus using his pact with the devil to seduce his followers and the conversion of his followers to Christianity by Paul are told in Actus Petri cum Simone and Passio Sanctorum Apostolorum Petri et Pauli. ${ }^{10}$ Even from these early sources, one can see an increasingly important link between heretics and the devil.

Saint Augustine's (354-430) On Christian Teaching, completed about 426, states that all pagan gods are actually demons disguised with whom humans can enter pacts for the purpose of personal glorification. ${ }^{11}$ Augustine's theology was crucial for later theologians such as Thomas Aquinas (1225-1274). Aquinas in his treatises on sorcery, Summa contra gentiles, asserted that "to be a sorcerer

\footnotetext{
${ }^{6}$ Jolly, "Medieval Magic: Definitions, Beliefs, Practices," 12-13.

7 The use of Jolly's period within the paper will act as a way of clarifying the time period based on what was occurring within Christian thought. The use of each period will act as an indicator not only of the period based on the century, but also the level of persecution enacted towards witches. Each period sees an escalation in the attitude of intolerance towards witches, or those believed to be witches, based on the focus of other groups, Jews and heretics, outside of Christian society. For example in the conversion period or the first period there is some focus on sorcerers and magicians but the focus is primarily on other groups such as Jews and pagans. Whereas in the second period witches are drawn into the group known as heretics and heretics become the ultimate enemy of the church. Lastly the third period in the fifteenth century indicates a shift to viewing witches as an evil by themselves.

8 Alan Charles Kors and Edward Peters, Witchcraft in Europe 400-1700: A Documentary History (Philadelphia: University of Pennsylvania Press, 2001), 41-42.

9 Michael Bailey, "The Age of Magicians," Magic, Ritual \& Witchcraft 3, no. 1, 4-5.

10 Alberto Ferreiro, "Simon Magus, Dogs, and Simon Peter," in The Devil, Heresy and Witchcraft in the Middle Ages: Essays in Honor of Jeffrey B. Russell, ed. Alberto Ferreiro (Brill: Library of Congress Cataloging-in-Publication Data, 1998), 45-51.

11 Augustine, "On Christian Teaching: Book II," in Witchcraft in Europe 400-1700: A Documentary History, ed. Alan Charles Kors and Edward Peters (Philadelphia: University of Pennsylvania Press, 2001), 44-47.
} 
was to be inhuman." 12 In both Augustine and Aquinas' writings the idea of the "maleficus" begins to emerge. The "maleficus", which had meant wrongdoing in earlier periods, had by the eighth and ninth centuries through a close association with the devil came to mean malevolent sorcery. By the fifteenth century "maleficus" solely meant to have a pact with Satan. ${ }^{13}$ Thus it is possible, using Augustine to find the roots of the idea of the satanic pact from $400 \mathrm{CE}$ and even earlier using sources surrounding Simon Magus, to trace the roots of the Satanic pact to the early part of Jolly's "conversion period." However, both Augustine and Aquinas remark in their treatises the satanic pact was not specific to sorcerers. The pact was a rationalization for intolerance toward Jews and heretics throughout the Middle Ages.

The connection between the satanic pact and the witch was in Christian imagination only a small step away from devil worship. Particularly because this pact entailed the glorification of the devil which, in relation to heresy, was already commonplace within medieval thought. The heretics of Orleans, one of the first groups prosecuted and punished as heretics, had charges of devil worship laid against them in 1122. Norman Cohn explained medieval Christians were willing to believe stories about devil worship and satanic pacts because of pre-existing myths and beliefs about satanic cults. ${ }^{14}$ The belief in satanic sects appeared later with the witch accusations during Jolly's period of the "witch-craze." The Council of Toulouse's The Witches' Sabbath, written during the fourteenth century, detailed the confessions of Anne Marie de Georgel and Catherine, the wife of Delort, two women allegedly seduced by Satan and pledged to worship him. ${ }^{15}$ Cohn demonstrates how the same beliefs seen in the allegations against the women named above were dominant in Christian discourse about heretics even before the twelfth century in Christian and pagan folklore.

In his book The Formation of a Persecuting Society: Authority and Deviance in Western Europe 950-1250 R. I. Moore examines the tumultuous relationship between the Jews and Christians of medieval Europe. Moore states, "all Jews everywhere form a conspiratorial body set on ruining and then dominating the rest of mankind." 16 The intolerance the Jews faced as a predominant Other within early medieval society was similar to the intolerance witches faced in later periods. Documents from each of Jolly's three periods in the Middle Ages repeat similar accusations against Jews, heretics, and witches. Monodiae, the autobiography of first crusade historian Guibert of Nogent written around 1115, recalls tales connecting Jews, sex, sorcery and Satan. Guibert's autobiography was one of the first texts to connect these themes which, by 1450 , had become prevalent in witch lore. ${ }^{17}$ The similarities between stories about heretics and about witches can be partially attributed to the twelfth century paradigm which is identified by Jolly which placed magic, sorcery, and paganism under the umbrella term of heresy. ${ }^{18}$ This paradigm is identified as a visible shift in Christian thought from the

12 Thomas Aquinas, "From the Summa contra gentiles: Sorcery and the World of Nature," in Witchcraft in Europe 4001700: A Documentary History, ed. Alan Charles Kors and Edward Peters (Philadelphia: University of Pennsylvania Press, 2001), 93.

${ }^{13}$ Russell and Alexander, 46.

14 Norman Cohn, "The Demonization of Mediaeval Heretics," in The Witchcraft Reader ed Darren Oldridge (New York: Routledge, 2002), 50.

15 Alan Charles Kors and Edward Peters, Witchcraft in Europe, 1100-1700; a Documentary History (Philadelphia: University of Pennsylvania, 1972), 95.

16 Richard Moore, The Formation of a Persecuting Society: Authority and Deviance in Western Europe 950-1250 (Malden, MA: Blackwell Publishing, 2007), 33.

${ }^{17}$ Moore, 33.

${ }^{18}$ Jolly, 20-21.

However, it should be noted witchcraft and sorcery, with the exception of scholarly or courtly magic, had been marked as heresy from as early as the eighth century. It was during the tenth century there was an increase in the similarities existing between the charges of heretics and those later attached to witches. 
Augustinian paradigm: of demonic association with paganism and magic, to the Aristotelian paradigm: of heresy and demonic association.

After the 1100s, members of heretical groups such as the Cathars and the Waldensians were assigned traits similar to those of later witches. In 1409 anti-Pope ${ }^{19}$ Alexander V labelled newly emerging sects of Christianity heretics and publicly condemned them. Alexander claimed these sects were made up of "Christians and Jews who are sorcerers, diviners, invokers of demons, enchanters, conjurers, superstitious people, augurs, practitioners of nefarious and forbidden arts, and that all of these [sects] stain and pervert the Christian people." ${ }^{20}$ A letter from Alexander V to inquisitor Pontus Fougeyron is indicative of another shift in witch lore. Just as earlier heretics could only exist within sects, the concept of an individual sorcerer was no longer imaginable outside the concept of a sect of witches. In turn the concept of the sect played a vital role in the development of the myth of the night-ride and the witches' Sabbath; the nocturnal meetings of witches. ${ }^{21}$ However, it is vital to note Alexander V's letters and decrees did not hold the same weight as they would have if Alexander had been the only Pope in Europe. At the time Alexander was pope there were two other popes in Europe and Alexander was considered the anti-pope. Alexander was eventually overthrown and his decrees overturned, but his letter illustrates the shift in the conception of witches and sorcerers in Christian thought, because it illustrates the ideas common within Christian thought permeated even the higher levels of Christianity.

\section{The Night-ride}

The night-ride has very early beginnings and is present within treatises from as early as the tenth century. Common beliefs, which reflected previous lay beliefs, existed between the upper etalons of the medieval church, bishops and popes, and the common people who were often just marginally Christian or only Christian by name. The co-existence of Christian and non-Christian beliefs illustrates how the church attempted to bring Christianity into the lower orders of society. However, much lay magic and beliefs were discouraged by the Church. Both of the inquisitors Bernard Gui and Nicholas Eymeric included folklore in their writings. Gui in his Directorium wrote about the "fairy women" who travelled together during the night. The obvious effect of such statements is to discourage lay magic by associating it with the emerging concept of diabolically organized sects of witches. Eymeric shifted the responsibility of witchcraft onto those people who "practiced it." Earlier documentation of "witchcraft" indicated participants in the night-ride were simple people who had been seduced by the devil. ${ }^{22}$ From the early accounts of the night-ride onwards the role Satan the seducer became increasingly important.

One of the early accounts of the night-ride comes from Regino of Prüm in the Canon Episcopi written in 906. The Canon Episcopi holds striking similarities, which will be examined later, to the myth of the witches' Sabbath which emerged in later periods. Regino of Prüm states in his treatise that:

[...]some wicked women, who have given themselves back to Satan and been seduced by the illusions and phantasms of themselves back to Satan and been

\footnotetext{
${ }_{19}$ An anti-pope is an individual who actively opposes the legitimate religious claim of the Pope in power with his own claim to lead the Catholic, or pre-reformation, Church. The existence of an anti-pope was problematic for the Pope, because they would actively compete for the title of Pope or claim to be the Pope.

20 Pope Alexander V, "Letter to Pontus Fougeyron on New Sects (1409)," in Witchcraft in Europe 400-1700: A Documentary History, ed. Alan Charles Kors and Edward Peters (Philadelphia: University of Pennsylvania Press, 2001$), 153$.

${ }^{21}$ Kors and Peters, 400-1700, 152-153.

${ }^{22}$ Michael D. Bailey, "From Sorcery to Witchcraft: Clerical Conceptions of Magic in the Later Middle Ages," in Speculum, Vol. 76, No. 4 (Oct., 2001), 975-976.
} 
seduced by the illusions and phantasms of demons, believe and profess that, in the hours of night, they ride upon certain beasts with Diana, the goddess of pagans, and an innumerable multitude of women, and in the silence of the night traverse great spaces of earth, and obey her commands as of their lady, and are summoned to her service on certain nights. ${ }^{23}$

Roughly a hundred years later Burchard of Worms related a similar version of the night-ride. This treatise contains even more parallels between the night-ride and the witches' Sabbath. Carlo Ginzburg's Ecstasies: Deciphering the Witches' Sabbat explores two vital differences between the treatises of Regino and Burchard. ${ }^{24}$ Burchard mistakenly attributes the recorded origins of the night-ride to the council of Ancyra in $314 .{ }^{25} \mathrm{He}$ also added Herodias, in the original Latin text of his treatise, to the goddess Diana's name. ${ }^{26}$ The addition of Herodias to Diana adds a scriptural element to the story of the night-ride and indicated a connection between Diana and the Jewish king Herod who, in Christian scripture, attempted to kill the baby Jesus. ${ }^{27}$ This connection implied a link between the Jews, "their king" Herod, and Diana who had no relation to the Jewish religion, but because she was a pagan Goddess inherently worked at destroying Christianity. Burchard's 1008 account of the night reads,

...some wicked women, turned back after Satan, seduced by illusions and phantoms of demons, believe and affirm: that with Diana, a goddess of the pagans, and an unnumbered multitude of women, they ride on certain beasts and traverse many areas of the earth in the stillness of the quiet night, obey her commands as if she were their mistress, and are called on special nights to her service?28

During the "conversion period," the period when both Regino of Prüms and Burchard of Worms wrote, magic was condemned, but the punishments for witchcraft were not as severe as in later centuries. Regino tells how women who took part in this ritual, although deceived by Satan, were still to be expelled from the church, an extremely severe punishment for the period. ${ }^{29}$ Burchard of Worms states that women who took part in the night-ride and people who believed in the night ride must perform penance for two years on appointed fast days, a lesser punishment than expulsion. ${ }^{30}$ Burchard of Worms reserved the extreme punishment of expulsion for those people who bragged

\footnotetext{
${ }^{23}$ Regino of Prüm, "A Warning to Bishops, the Canon Episcopi," in Witchcraft in Europe 400-1700: A Documentary History, ed. Alan Charles Kors and Edward Peters (Philadelphia: University of Pennsylvania Press, 2001), 60-63.

${ }^{24}$ Ginzburg's argument surrounding witches in the medieval Europe represents only one side of the ongoing discussion. There other theories which disagree with Ginzburg's theory on fear of the remnants of an ancient pagan group which led to the extreme persecution of the remaining practitioners. Although this is indeed true for specific areas within Europe it cannot be applied to all of Christendom as Ginzburg asserts.

25 The Council of Ancyra examines the years of penance which must be paid for the perpetration of mortal sins such as murder, adultery, etc. The only canon which addresses the sin of divination is Canon 24, "They who practice divination, and follow the customs of the heathen, or who take men to their houses for the invention of sorceries, or for lustrations, fall under the canon of five years [penance], according to the prescribed degrees; that is, three years as prostrators, and two of prayer without oblation."

"Documents of the Council of Ancyra AD 314," trans Henry R. Percival, accessed 14 Nov, 2011, http://www.voskrese.info/spl/ancycanon.html

${ }^{26}$ Formally the title was not added in Church Canon until the Council of Trier in 1310.

${ }^{27}$ Carlo Ginzburg, Ecstasies: Deciphering the Witches' Sabbath (New York: Pantheon Books, 1991), 90-94.

${ }^{28}$ Burchard of Worms, "The Corrector, sive Medicus," in Witchcraft in Europe 400-1700: A Documentary History, ed. Alan Charles Kors and Edward Peters (Philadelphia: University of Pennsylvania Press, 2001), 65.

${ }^{29}$ Regino of Prüm, 62.

${ }^{30}$ Burchard of Worms, 65.
} 
about using magic to create love or hatred in others, often through potions, from the nocturnal meetings with Diana. ${ }^{31}$ It is important to note Regino's Canon Episcopi held enormous power throughout the Middle Ages because of its supposed fourth-century authorship. In reality, the Canon Episcopi was written as a legal document around 906. The false antiquarian roots of the canon created an association between Diana and Satan that lasted until the end of the "witch-craze" in the eighteenth century. ${ }^{32}$ By the 1450 s the night-ride, the diabolical mode of transportation for these "wicked women" to their nocturnal meetings with a pagan goddess, had emerged as a vital aspect of the witches' Sabbath. ${ }^{33}$

\section{The Witches' Sabbath}

During the "conversion period" sorcery was seen as an individual affliction, while heresy was seen as a joint affliction large group of people suffered from. However, as the connection between heretics and witches developed the concept of a group or sect of witches and the phenomenon of diabolical, collaborative sorcery formed, which was reflected in Johannes Nider's Formicarius (1435-38). ${ }^{34}$ The same group mentality projected on witches after the fifteenth century arose out of the secret meetings of heretical groups such as the Cathars and Waldensians. ${ }^{35}$ This particular phenomenon is explained by anthropologist Clifford Geertz in his article "Shifting Aims, Moving Targets: On the Anthropology of Religion." Geertz states individuals have a tendency to "replace one obscurity with another." This concept, when applied to a group situation, is present in the paradigm shift from "witchcraft and paganism" to "witchcraft as a heresy" to "witchcraft as a separate entity from heresy." Cohn acknowledges the replacement of "obscurities" in relation to the witches' Sabbath, describing it as "an aggressive stereotype that [was] applied in former times to Jews, the early Christians and mediaeval heretical sects." ${ }^{37}$ Ginzburg examines a similar process of "replacing obscurities": the obscurities within Christian communities, in chronological order according to Ginzburg, were lepers, Jews and witches. Each internal enemy was dealt with in a similar manner with similar charges laid against them and similar language used such as heretical "synagogues". 38

Since Guibert of Norgent in the mid-twelfth century a connection between sorcery and Judaism had existed. ${ }^{39}$ In his autobiography, Guibert recalls an anecdote about a monk who, in return for mastery of magic, purchased medication from a Jew in order to sell his soul to the devil. ${ }^{40}$ Similarly, twelfthcentury records from Conrad of Marburg and Pope Gregory IX show accusations of orgies and devil worship in Waldensian and other heretical sects. After the death of Conrad of Marburg in 1233 these claims were declared false by the archbishop of Mainz and David of Augsburg. Still the rumours of heretical orgies and devil worship remained present within Christian thought. During the twelfth-century Walter Map called the secret meetings of heretical groups in their diabolical

\footnotetext{
31 Ginzburg, 91.

32 Russell and Alexander, 53-54.

33 Rainer Decker, Witchcraft and the Papacy: An Account Drawing on the Formerly Secret Records of the Roman Inquisition (Darmstadt: Primas Verlag, 2003), 40.

34 Edward Peters, "The Medieval Church and State on Superstition, Magic and Witchcraft: From Augustine to the Sixteenth Century," in in Witchcraft and Magic in Europe: The Middle Ages, ed. Bengt Ankarloo and Stuart Clark (Philadelphia: University of Pennsylvania Press, 2002), 234.

${ }^{35}$ Decker, 42.

36 Clifford Geertz, "Shifting Aims, Moving Targets: On the Anthropology of Religion," in Journal of the Royal Anthropological Institute (Mar 2005: Vol. 11 Issue 1, pp 1-15), 5.

${ }^{37}$ Carlo Ginzburg, "Deciphering the Witches' Sabbat," in The Witchcraft Reader ed. Darren Oldridge (London: Routledge, 2002), 120.

38 Ginzburg, 121.

${ }^{39}$ Kors and Peters, 400-1700, 72.

40 Moore, 33.
} 
synagogues, another blatant connection with Judaism and the diabolical. An implicitly negative association existed between the Jewish holy day and meeting place within Christian thought. Map provides extensive documentation of the diabolical acts Christians believed were performed by the heretics during their "synagogues":

They [heretics] do not sing hymns or repeat them distinctly, but hum through clenched teeth and pantingly feel their way toward the place where they see their lord. When they have found him they kiss him, each the more humbly as he is the more enflamed by frenzy- some the feet, more under the tail, most the private parts. $^{41}$

Conversely, in the fourteen-century, Bernard of Gui stated in The Inquisitors Guild, the heretics referred to the Christian church as "synagogues of Satan" implying the heretics slandered the name and word of God. ${ }^{42}$ The term "synagogue of Satan" was taken directly from the bible, Revelations 2:9, and applied to the Jewish population. ${ }^{43}$ By the fifteenth century, the term Sabbath had replaced the term synagogue which had been used throughout the Middle Ages. ${ }^{44}$ One can see the conditions necessary for the creation of the witches' Sabbath as a concept and how pre-existing ideas about heresy made the belief in a diabolical sect separate from Christianity believable.

Before the witch-craze began many of the acts which supposedly occurred during the witches' Sabbath had allegedly taken place at the secret meetings of heretics or was believed to have been perpetrated by the Jewish community. Witchcraft, heresy and Judaism played a vital role within the Christian church, because they represented the opposition to Christianity. ${ }^{45}$ Since Christianity was inherently good and everything done within Christian ritual was good, logically, everything done by heretical and Jewish groups was inherently bad. The only way the church could describe these groups was "diabolical". The term diabolical in this situation functioning as "concocted jargon." 46 Since Christians glorified God, everyone who was not Christian in their "diabolical" traditions must be desecrating the very image of God in all its forms. This phenomena of the diabolical Others actively seeking to desecrate and destroy Christianity is found within the paradigm outlined by Jolly that took shape during the conversion period, 300 to $900 \mathrm{CE}$, and emerged in the twelfth-century. ${ }^{47}$

\section{Orgies, Desecration, Infanticide, and Cannibalism}

Swiss scholar Katrin Utz Tremp's Von der Häresie zur Hexerei: "Wirkliche" und imaginäre Sekten im Spätmittelalter examines the connections existing between the heretics of the late Middle Ages and the fifteenth-century witches. Tremp states that after the 1100s there was overlap between witches and heretical groups in Christian imagination. ${ }^{48}$ As has been repeatedly shown, the supposed traditions of the witches' Sabbath were not unique to the witches of the fifteenth century. Geertz in "Shifting

\footnotetext{
${ }^{41}$ Cohn, 37.

42 Bernard Gui, The Inquisitor's Guide: A Medieval Manual on Heretics, trans by Janet Shirley (London: Ravenhall Books, 2006), 35 .

43 "I know your afflictions and your poverty-yet you are rich! I know about the slander of those who say they are Jews and are not, but are a synagogue of Satan.” (Rev 2:9 NIV)

Moore, 33.

${ }_{44}$ Russell and Alexander, 62.

45 Stuart Clark, Thinking with Demons: The Idea of Witchcraft in Early Modern Europe (New York: Oxford University Press, 1997), 7.

46 Geertz, 6.

${ }^{47}$ Jolly, 13-15.

48 Michael Bailey, "Review of Von der Häresie zur Hexerei: "Wirchliche” und imaginäre Sekten im Spätmittelalter by Katrin Utz Tremp," in Magic, Ritual, and Witchcraft (Winter 2010), 255-257.
} 
Aims, Moving Targets" examined how people categorize the Other based on how their beliefs of the Other relate to the beliefs about ones own culture. People tend to place different groups into categories that resemble other groups outside of their own. ${ }^{49}$ Medieval Christian thought placed all non-Christian religious groups into a single overarching and overlapping category. Overarching, because it included Jews, heretics, witches, and Muslims, who were also categorized as heretics, and overlapping, because the same charges existed between the different groups. ${ }^{50}$ The rumours of Jewish and heretical sects desecrating hosts, participating in diabolical orgies, killing children and cannibalising children had been present within Christian thought long before the fifteenth century.

Similarly, the ritual orgy of the witches' Sabbath was a common element in twelfth century lore about the secret meetings of heretical groups, but had come into existence long before. In $150 \mathrm{CE}$ Justin Martyr accused heretics of holding secret orgies. This accusation was repeated against the practitioners of Manichaeism, an early dualist religion, in the fifth century by Augustine. ${ }^{51}$ Medieval Christian society viewed sex as a purely procreative process with no place for pleasure. Having sex outside of procreation was sinful and innately unchristian. Nicholas Eymeric accepted these rumours surrounding the sexuality of heretics and stated, "It is better to satisfy one's lust by any kind of evil act than to be harassed by the goading of the flesh." 52 Orgies were used to cast heretics as inhuman, particularly in regards to the Church's philosophy on sex as a procreative tool. Therefore, heretics, defined as the binary opposite of good Christians, were cast as sexually promiscuous and often incestuous in their orgies. There was no limit to the moral degradation of heretics within the Christian imagination where they were inherently seen as inhuman. ${ }^{53}$ An example is the Cathars whose nocturnal meetings supposedly included a sermon, a heretical sacrament, feasting, drinking, and an orgy. Not unique to Cathar meetings, orgies were commonly ascribed to the "diabolical sects" of heretics. In 1175, similar accusations arose against a group of heretics in Verona. According to the trial records of the Verona heretics' nocturnal meetings began with a sacrilegious sermon and concluded with an orgy. ${ }^{54}$ The image of the immoral heretic had become exceedingly popular about a century before the "witch-craze". Nicolas Eymeric's Directorium Inquisitorum from about 1368 provides an account the Aragon Waldensian heretics' meetings "In the dark it is lawful for any man to mate with any woman, without distinction, whenever and as often as they are moved by carnal desires."

From the twelfth to the fifteenth-century the concept of maleficent or diabolical magic was materializing. The idea of the maleficent witch had cemented itself in the Christian imagination by the fifteenth century as is reflected in Jacob Sprenger and Heinrich Krämer's Malleus Maleficarum, The Hammer of Witches. As well as the charge of diabolical orgies another charge against witches was host desecration, also laid against medieval Jews. However, host desecration only became a feasible charge after the Fourth Lateran Council in 1215 established the dogma of transubstantiation. Before

\footnotetext{
${ }^{49}$ Geertz, 5.

50 "Whoever invokes the aid of Mohammed, even if he does nothing else, falls into manifest heresy."

-Nicholas Eymeric. Quoted in Kors and Peters, 400-1700, 90.

51 It must be noted that Augustine himself was a convert from Manichaeism and much of his knowledge about Manichaeans was based on this. However, his conversion also acted as a powerful tool against Manichaeism because of supposed insider knowledge of Manichaean traditions. Similar cases of this are present throughout the Middle Ages, for example Herman the Jew and anti-Jewish polemic within his manuscript.

Eliade, 167.

52 Cohn, 39.

53 ibid, 38-40.

${ }^{54}$ Mircea Eliade, "Some Observations on European Witchcraft," in History of Religions (4: vol 3, 1975$), 166$.

55 Cohn, 39.
} 
1215, the Eucharist was not accepted as the literal body of Christ by the entire Church and therefore the charge of host desecration did not carry the same weight as it did after 1215.

During the "witch-craze," witches were often accused of using the Eucharist to perform magic, stories of witches desecrating the host during their Sabbaths were commonplace. Such a charge against witches can be seen against the witches of Normandy during the "witch-craze." 56 In the letter to all Inquisitors of 1437, Pope Eugenius IV stated "In their sorcery they are not afraid to use the materials of Baptism, the Eucharist, and other sacraments." ${ }^{57}$ In 1320, about a hundred years before Eugenius, orders from Cardinal William Godin, in the name of Pope John XXII, gave inquisitors the ability to persecute heretics who "abused a consecrated host or any other sacrament for fortunetelling or for harmful magic." 58 The Church passed this order to inquisitors because it was believed heretics were desecrating the host in order to tell fortunes and perform other magic. If the Church had not believed heretical and Jewish groups were desecrating the host to perform magic then it would not have needed to pass such orders. The second fear of the Church was that heretics desecrated the host to undermine both the Church and Christian faith. Similar host desecration myths emerged during the thirteenth and fourteenth century about European Jews. In Gentile Tales: The Narrative Assault on Late Medieval Jews Miri Rubin examines the power and scope of these stories in Western Europe. These charges claimed that Jews stole or convinced a Christian to steal a Eucharist then proceeded to cut, stab, boil, and hide the bleeding Eucharist from the Christians. The stories all conclude in the same way: the stolen host is discovered and the Jews are mercilessly punished or slaughtered. The host desecration stories about heretics ended the same as those against Jews.

Adding to the already promiscuous and sacrilegious image of the witch in Christian thought was the myth of infanticide and cannibalism. Stories about heretical groups attacking children, sucking their blood, consuming their flesh, and creating potions or making powder from their corpses were not unusual within medieval society. ${ }^{59}$ Richard Kieckhefer theorizes that stories of infanticide may have been a reaction to medieval Europe's high infant mortality rate. The children murdered by witches were often un-baptised babies or the offspring of a previous Sabbath's orgy. ${ }^{60}$ Kieckhefer draws a parallel between the Sabbath, where witches "sucked the blood" of the children they murdered and "ate the bodies", and the Christian Eucharist. ${ }^{61}$ Similar accusations of a twisted Eucharist were levied against heretical groups such as the Fraticelli in Italy. Inquisitors reported that the Fraticelli, "from the babies born [from their orgies], take one little boy as a sacrifice. They make a fire, around which they stand in a circle. They pass the little boy from hand to hand until he is quite dried up. Later they make powders from the body. They put these powders in a flask of wine. After the end of mass they give some of this wine to all taking part; each drinks once from the flask, by way of communion." ${ }^{2}$ Such accusations were also imposed against Waldensians, Cathars and Jews. In 1329, similar accusations were levied against Acelinus of Tresserve, a Jew, and his Christian counterpart, Jacques of Aiguebelle, in the Duchy of Savoy claimed the two men had slaughtered Christian boys to use their flesh and blood to cook a Passover dish. However, these charges against Acelinus and Jacques

\footnotetext{
56 Apps and Gow, 33.

${ }^{57}$ Kors and Edwards, 1100-1700, 101.

${ }^{58}$ Decker, 32.

59 Richard Kieckhefer, "Avenging the Blood of Children: Anxiety Over Child Victims and the Origins of the European Witch Trials," in The Devil, Heresy and Witchcraft in the Middle Ages: Essays in Honour of Jeffrey B. Russell ed. Alberto Ferreiro (Brill: Library of Congress Cataloguing-in-Publication Data, 1998), 92-95.

${ }^{60}$ Ibid, 97.

61 Ibid, 102.

62 Cohn, 45.
} 
were dismissed when Pope Innocent IV and Gregory X denied the use of Christian blood in Jewish rituals. ${ }^{63}$ The Jews were the only non-Christian group to receive papal assistance from child murder accusations. However, both anti-Jewish sentiments and anti-heretical sentiments continued into the early modern period.

The activities the Christians believed took place during the witches' Sabbath correspond with similar stories about heretics and Jews. Geertz acknowledged societies compartmentalize the Other present within their societies "import abstractions" and attribute them to outsider groups. ${ }^{64}$ Orgies, host desecration, infanticide and cannibalism were part of medieval Christian thought about witches, heretics and Jews. The concrete image of the witch present in the fifteenth century at the start of the mass witch trials was possible because of how Jewish and heretical sects had been viewed and persecuted since before the eleventh century.

\section{Conclusion}

Throughout this paper I have examined how witches were viewed by medieval Christians. It considered how Christian beliefs about non-Christian minorities established the conditions for the persecution of witches during Jolly's third period, the early fourteenth and the fifteenth century. ${ }^{65}$ The relationship between Christians and non-Christians was exceedingly complicated because belief and reality did not necessarily correspond. However, as historian Stuart Clark states, there was a definite correspondence between medieval Christian beliefs and medieval Christian reality. ${ }^{66}$ This correspondence is implicit to the overarching subtext of the paper: the similarities between different minorities" "traditions" are a medieval Christian method of categorizing. Essentially the line between "superstitio", ascribed to all religions other then Christianity, and "religio," true religion (i.e. Christianity), categorized everything outside of Christianity as false and therefore evil. ${ }^{67}$

The idea of witches did not emerge suddenly at the dawn of the fifteenth century nor were the changes laid by inquisitors unique to witches. Similar charges were present across Christendom against heretical groups such as Cathars and Waldensians where little is known about the actual practices of these groups outside of Christian sources. The same charges that were levied against heretics and witches were also raised against the Jewish community. These charges involved: but were not exclusive to, a pact with Satan, secret late night-rides to nocturnal meetings that later, through anti-Jewish and anti-heretical polemic, became the witches' Sabbath. Diabolical traditions practiced at the "Sabbath" or "Sabbat" such as orgies, host desecration, infanticide and cannibalism were allegedly witch, heretic, and Jewish "traditions." The persecution of supposed witches in the later Middle Ages would not have been imaginable if these groups had not faced similar persecution at the hands of the Christians in the centuries preceding the outbreak of the witch-craze.

\footnotetext{
63 Miri Rubin, Gentile Tales: The Narrative Assault on Late Medieval Jews (Philadelphia: University of Pennsylvania Press, 1999), 108.

${ }^{64}$ Geertz, 6.

65 Jolly, 23-29.

${ }^{66}$ Stuart Clark, Thinking with Demons: The Idea of Witchcraft in Early Modern Europe (Oxford: Clarendon Press, 1997$), 7$.

${ }^{67}$ Peters, 178-179.
} 


\section{Biblioraphy}

Apps, Lara, and Andrew Colin. Gow. Male Witches in Early Modern Europe. Manchester, UK: Manchester UP, 2003.

Bailey, Michael D. 2008 “The Age of Magicians.” Magic, Ritual \& Witchcraft 3, no. 1: 1-28.

Bailey, Michael D. 2001. "From Sorcery to Witchcraft: Clerical Conceptions of Magic in the Later Middle Ages." Speculum 76, no. 4: 960-990.

Bailey, MICHAEL D. 2010. „Von der Häresie zur Hexerei: ,Wirkliche’ und imaginäre Sekten im Spätmittelalter.“ Magic, Ritual \& Witchcraft 5, no. 2: 255-258.

Clark, Stuart. Thinking with Demons: the Idea of Witchcraft in Early Modern Europe. Oxford [England: Clarendon, 1997.

Cohn, Norman. “The Demonization of Mediaeval Heretics." The Witchcraft Reader. Ed. Darren Oldridge. London: Routledge, 2002. 36-52.

Decker, Rainer. Witchcraft and the Papacy: an Account Drawing on the Formerly Secret Records of the Roman Inquisition. Charlottesville, VA: University of Virginia, 2008.

Eliade, Mircea. 1975. "Some Observations on European Witchcraft.” in History Of Religions 14, no. 3: 149-172.

Ferreiro, Alberto. "Simon Magus, Dogs, and Simon Peter." The Devil, Heresy, and Witchcraft in the Middle Ages: Essays in Honor of Jeffrey B. Russell. Ed. Alberto Ferreiro. Leiden: Brill, 1998. 45-90.

Geertz, Clifford. 2005. "Shifting Aims, Moving Targets: On the Anthropology of Religion." Journal Of The Royal Anthropological Institute 11, no. 1: 1-15.

Ginzburg, Carlo. "Deciphering the Witches' Sabbat." The Witchcraft Reader. Ed. Darren Oldridge. London: Routledge, 2002. 120-128.

Ginzburg, Carlo. Ecstasies: Deciphering the Witches' Sabbath. Chicago: University of Chicago, 2004.

Gui, Bernard. The Inquisitor's Guild: A Medieval Manual on Heretics. Trans. Janet Shirley. Linden: Ravenhall, 2006.

Jolly, Karen, Catharina Raudvere, and Edward Peters. Witchcraft and Magic in Europe: the Middle Ages. Ed. Bengt Ankarloo and Stuart Clark. Philadelphia: University of Pennsylvania, 2002.

Kieckhefer, Richard. "Avenging the Blood of Children: Anxiety Over Child Victims and the Origins of the European Witch Trials." The Devil, Heresy, and Witchcraft in the Middle Ages: Essays in Honor of Jeffrey B. Russell. Ed. Alberto Ferreiro. Leiden: Brill, 1998. 91-110.

Kieckhefer, Richard. "Witch trials in Mediaeval Europe." The Witchcraft Reader. Ed. Darren Oldridge. London: Routledge, 2002. 25-35.

Kors, Alan Charles., Edward Peters, and Alan Charles. Kors. Witchcraft in Europe, 400-1700: a Documentary History. Philadelphia: University of Pennsylvania, 2001.

Kors, Alan Charles, and Edward Peters. Witchcraft in Europe, 1100-1700; a Documentary History. Philadelphia: University of Pennsylvania, 1972.

Moore, R. I. The Formation of a Persecuting Society: Authority and Deviance in Western Europe, 950-1250. Malden, MA: Blackwell, 2007.

Rubin, Miri. Gentile Tales: the Narrative Assault on Late Medieval Jews. Philadelphia: University of Pennsylvania, 2004.

Russell, Jeffrey Burton., and Brooks Alexander. A History of Witchcraft: Sorcerers, Heretics and Pagans. New York: Thames \& Hudson, 2007. 